УДК 622.012.2.013.3 (477)

ОБОСНОВАНИЕ ЦЕЛЕСООБРАЗНОСТИ УСКОРЕННОГО РАЗВИТИЯ

ГОСУДАРСТВЕННЫХ ШАХТ УКРАИНЫ

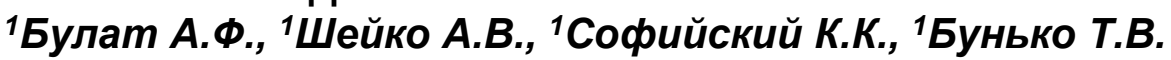

${ }^{1}$ Институт геотехнической механики им. Н.С. Полякова НАН Украинь

\author{
ОБҐРУНТУВАННЯ ДОЦІЛЬНОСТІ ПРИСКОРЕНОГО РОЗВИТКУ \\ ДЕРЖАВНИХ ШАХТ УКРАЇНИ

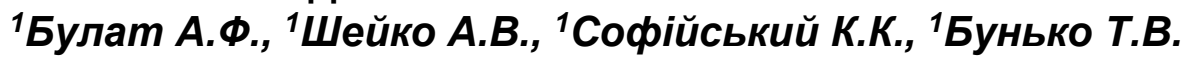 \\ ${ }^{1}$ Інститут геотехнічної механіки ім. М.С. Полякова НАН Украӥни
}

\title{
GROUNDS FOR MORE RAPID DEVELOPMENT OF UKRAINIAN STATE MINES
}

${ }^{1}$ Bulat A.F., ${ }^{1}$ Sheiko A.V., ${ }^{1}$ Sofiyskiy K.K., ${ }^{1}$ Bunko T.V.

${ }^{I}$ Institute of Geotechnical Mechanics named by N. Polyakov of National Academy of Science of Ukraine

Аннотация. Внутренний рынок Украины испытывает дефицит в товарном каменном угле в объёме

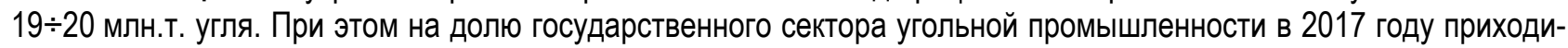
лось всего 4,4млн. тонн добытого угля. На импорт угля ежегодно расходуется 64 млрд.грн.

Альтернативным является решение по восстановлению промышленного потенциала шахт государственного сектора Украины путём их модернизаций на основе инноваций, заёмных инвестиций и лизинга. Одним из важных документов, нацеленных на решение этой задачи, является Новая экономическая стратегия Украины (НЭС) на период до 2035 года «Безопасность, энергоэффективность, конкурентоспособность». Реализация её положений позволит увеличить мощности действующих шахт, снизить себестоимость добычи и затраты на импорт угля, попутно добывать метан угольных месторождений, увеличить экономический потенциал и обеспечить энергетическую независимость Украины. Для развития шахт необходимы большие финансовые ресурсы \$1,0-1,5 млрд. USA. Их можно уменьшить на 20 $\div 30$ \% на основе научно-инновационного потенциала академических, отраслевых и учебных институтов Украины. Ускоренное развитие угольных шахт государственного сектора Украины обеспечит ежегодное увеличение богатства нации на \$3 млрд. USA.

Типичным угольным предприятием является шахта им. Д.Ф. Мельникова, развитие горных работ на которой (ввод двух дополнительных лав) позволит втрое (до 900 тыс.т/год) увеличить её мощность и снизить себестоимость добываемого угля с 1900 до 1000 грн./т. Повышение суммарной мощности шахт позволит до 2035 года полностью отказаться от импорта, покрыв его необходимую потребность в 21,5 млн.т/год. Произведен расчет необходимых для этого инвестиций и оценён срок их окупаемости.

Ключевые слова: промышленный потенциал шахт, себестоимость добычи, ускоренное развитие угледобычи, импорт угля, инвестиции, окупаемость.

На этапе становления Украины, как полноценного члена европейского сообщества, одним из приоритетных является вопрос обеспечения ее энергонезависимости. Для решения его необходима коренная реконструкция и развитие всех топливно-энергетических областей промышленности, и не в последнюю очередь - угольной. Значительная роль в этом принадлежит отечественной горной науке.

Одним из новейших документов, посвящённых развитию научного сопровождения угольной отрасли в Украине, явилось Постановление кабинета Министров Украины от 07.09.2011 г. № 942 «Про затвердження переліку пріоритетних тематичних напрямів наукових досліджень і науково-технічних розробокна період до 2020 року» [1].

Рассчитанным на более продолжительную перспективу документом из числа принятых в Украине в последние годы, является «Стратегия устойчивого 
развития «Украина-2020» [2], утверждённая Указом Президента Украины от 12 января 2015 года № 5, которая, в частности, предусматривает реформирование энергетики и реализацию программы энергоэффективности в рамках определённого вектора дальнейшего развития. Конкретизация и меры по решению отдельных её положений нашли отражение в Распоряжениях Кабинета Министров Украины от 27.05.2015 г. № 418-р (III. Модернізація інфраструктури. 3. Реформа вугільної промисловості) [3], от 24.05.2017 г. № 733-р «Про схвалення Концепції реформування та розвитку вугільної промисловості на період до 2020 року» [4] и ряде других документов. И, наконец, 1 июня 2017 года Министерство энергетики и угольной промышленности Украины представило на рассмотрение проект Новой энергетической стратегии Украины (НЭС) до 2035 года «Безопасность, энергоэффективность, конкурентоспособность» [5], предусматривающей завершение в основном к 2025 году реформирование энергетического комплекса Украины, достижение первоочередных целевых показателей по безопасности и энергоэффективности, обеспечения его инновационного обновления интеграции с энергетическим сектором ЕС.

Имплементация НЭС предполагается в три этапа:

a) реформирование энергетического сектора (до 2020 года). В этом она в определённой степени продолжает и расширяет положения Распоряжения Кабмина Украины от 07.09.2011 года № 942 с учётом современных реалий. Будет создан рынок угольной продукции. Реструктуризация угольной промышленности будет сопровождаться комплексом мер по подготовке перспективных государственных шахт к приватизации, ликвидации (консервации) убыточных государственных шахт, переход на самоокупающуюся добычу угля с переориентацией государственной поддержки на охрану труда, защиту окружающей природной среды, смягчению социальных и экологических последствий ликвидации (либо консервации)угольных шахт и социальной реконверсии регионов закрытия шахт в соответствии с лучшими европейскими практиками;

б) оптимизация и инновационное развитие энергетической инфраструктуры (до 2025 года). Будут осуществлены приватизация перспективных государственных шахт, подготовительные вопросы которой были решены на первом этапе, ликвидация (консервация) неэффективных шахт с выполнением планов смягчения социальных и экологических последствий для каждого предприятия, реализации программ социальной реконверсии регионов закрытия шахт, оптимизации экономических и технических показателей деятельности, сокращения и ликвидации регулирования и дотирования операционной деятельности угледобывающих и углеперерабатывающих предприятий после реинтеграции неконтролируемых территорий Донецкой и Луганской областей, достижения уровня добычи, обеспечивающего потребителей энергетического угля преимущественно топливом национальной добычи;

в) обеспечение устойчивого развития (до 2035 года). Будут достигнуты максимизация эффективности производства для собственных потребностей Украины и завершение мер по социальной реконверсии регионов и населённых пунктов, где проводилось закрытие шахт. 
«Стратегия...» определяет цели и задачи первого этапа реформ и детально описывает механизм достижения запланированных показателей и результатов. Цели и задачи второго и третьего этапов предусматривается уточнять один раз в три года при пересмотре «Стратегии...» на предмет актуализации.

По данным Государственной службы статистики Украины, структура общего первичного энергоснабжения (ОПЭС), которое рассчитывается как сумма производства (добычи), импорта, экспорта, международной бункеровки судов и изменения запасов энергоресурсов в стране, характеризовалась в 2015 году, к моменту принятия «Стратегии устойчивого развития «Украина-2020» высокой долей природного газа (28,9 \%, или 26 млн. т нефтяного эквивалента (т н.э.)). Доля атомной энергетики составляла 25,5 \% (23 млн т н.э.); угля - 30 \% (27 млн. т н.э.); сырой нефти и нефтепродуктов - 11,6 \% (10,5 млн. т н.э.); других источников энергии (возобновляемых) - 4 \% (3,6 млн. т н.э.).

С учётом ограниченности природных ресурсов в Украине, в 2015 году показатель импортозависимости составлял, с учётом поставок ядерного топлива, 51,6 \%, что обусловило риск для энергетической безопасности страны. Поэтому снижение импортозависимости является одним из ключевых приоритетов новой энергетической стратегии. Прогнозируется, что доля импортных компонентов в ОПЭС снизится до менее чем 50 \% уже к 2020 году и до менее чем 33 \% в 20252035 гг., в частности, за счёт возобновляемых источников энергии; увеличению собственной добычи природного газа; энергосбережения и повышения энергоэффективности с соблюдением высоких экологических стандартов. Роль угольной промышленности в этом процессе нельзя недооценивать, однако высоких результатов ожидать вряд ли приходится по ряду объективных и субъективных причин.

Как отмечалось выше, даже после сокращения добычи отечественного угля за счёт прекращения его поступления с временно оккупированных территорий Донецкой и Луганской областей, доля его в ОПЭС составляла 30 \%, т.е. оставалась значительной. Государственный сектор угольной промышленности Украины состоит из 33 шахт, переданных на баланс Национальной угольной компании (НУК). Из них не все являются рентабельными (по данным, озвученным министром угольной промышленности И. Носаликом, рентабельны «Южнодонбасская № 1», шахта «Им. Н.С. Сургая», отдельные шахты объединений «Торецкуголь» и «Львовуголь», шахта «Надежда»). Ввиду отсутствия средств на развитие шахт, объёмы добычи угля Минэнергоугля Украины характеризуются отрицательной динамикой. Так, за пятилетний период с 2013 г. по 2017 г. включительно, объём добычи уменьшился в два раза с 9 млн.т до 4,4 млн.т в год.

Из Госбюджета Украины ежегодно выделялись средства (табл. 1), однако при этом не предусматривались дотации для развития отрасли. Деньги выделялись только для закрытия шахт и поддержания Военизированной Государственной горноспасательной службы.

«Программой развития топливно-энергетического сектора Украины» предусмотрено закрыть 11 шахт (III-я группа), приватизировать 14 шахт (II-я группа) и 8 шахт оставить в собственности государства (I-я группа). 
В 2017 году себестоимость добычи угля на шахтах Минэнергоугля Украины составляла 2,5 тыс.грн./т. Наибольшей она была в ПАО «Лисичанскуголь» - 7,2 тыс.грн./т, в ГП «Торецкуголь» - 5,5 тыс.грн./т, в ГП «Первомайскуголь» 3,95 тыс.грн./т, в ГП «Мирноградуголь» - 3,75 тыс.грн./т, в ГП «Селидовуголь» - 3,5 тыс.грн./т.

Основным параметром, влияющим на себестоимость добычи угля, является производственная мощность шахты $A_{ш}$

$$
C=a+\frac{b}{A_{\text {шा }}}
$$

где, $a$ - удельные постоянные затраты на одну тонну угля, грн./т; $b$ - условнопостоянные расходы шахты тыс. грн.; $A_{ш}$ - производственная мощность шахты, тыс.т.

Значения параметров $a$ и $b$ определены для типичной шахты Донбасса ОП «Шахта им. Д.Ф. Мельникова» ПАО «Лисичанскуголь» (табл. 2).

Таблица 1 - Господдержка угольной отрасли

\begin{tabular}{|c|c|c|c|}
\hline Год & 2015 & 2016 & 2017 \\
\hline Господдержка, млрд. грн. & 1,2 & 1,4 & 1,4 \\
\hline
\end{tabular}

Таблица 2 - Значения параметров, влияющих на себестоимость угля

\begin{tabular}{|c|c|c|}
\hline \multirow{2}{*}{ Параметры } & \multicolumn{2}{|c|}{ Значение параметров } \\
\cline { 2 - 3 } & в \$ USA & в гривнах \\
\hline$a$ & $\$ 20$ USA $/$ & 520 грн./T \\
\hline$b$ & $\$ 16,6 \cdot 10^{6} \mathrm{USA} /$ год & $432 \cdot 10^{6}$ грн./год \\
\hline
\end{tabular}

На рис. 1 представлен график влияния производственной мощности шахты на себестоимость добычи угля. Как видно из рисунка, при мощности до 0,2 млн.т в год, что характерно для ряда старых шахт Украины, себестоимость добычи равна цене угольного товара на внутреннем рынке, и лишь после достижения этого показателя несколько снижается.

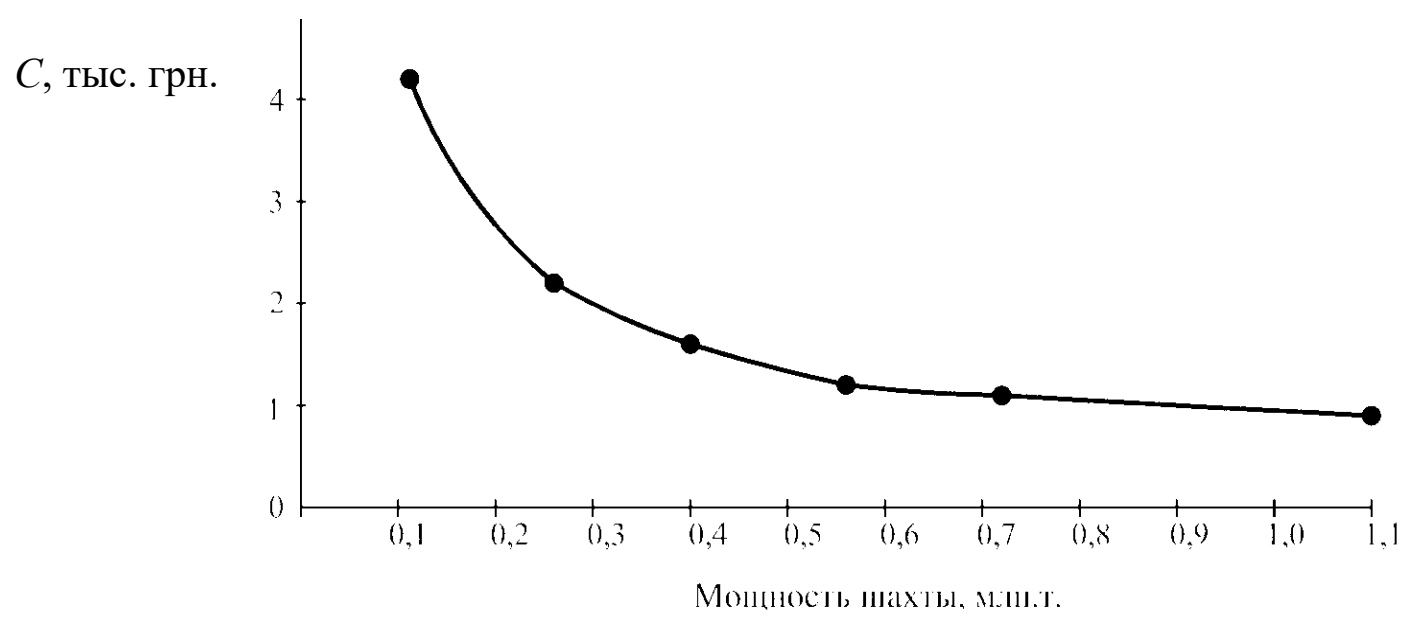

Рисунок 1 - График влияния мощности шахты на себестоимость добычи рядового угля

Потребность в инвестициях характеризуется следующими данными.

По программе 2016 года для развития предприятий угольной промышленности предусматривалось 1,4 млрд. грн. бюджетных средств, с увеличением годового объёма добычи от фактического - 5,8 млн.т. до 8,7 млн.т. угля в год. 
Удельные капитальные вложения на развитие шахт первой группы составляют $\sim 500$ грн./т или \$20 USA/т.

По экспертной оценке первого заместителя Министра энергетики и угольной промышленности А. Корзуна, добычу государственных шахт можно увеличить в 2,0-3,0 раза, при дополнительном финансировании от 2,5 до 3,5 млрд. грн., т.е. вместо 4,4 млн. т добывать 8,8 $\div 13,2$ млн.т угля в год. При этом удельные инвестиции составят:

- минимальные - 400 грн./т;

- максимальные - 600 грн./т;

- средние - 500 грн./т.

Представленные данные об удельных инвестициях характерны для шахт первой группы.

Для шахт второй группы, для которых необходимо подготавливать и оснащать лавы, удельные инвестиции больше. По опыту модернизации ОП «Шахта им. Д.Ф. Мельникова» удельные затраты на подготовку и оснащение участка с нагрузкой на лаву 1000 т в сутки (350 тыс.т в год) удельные инвестиции составляют \$40 USA/т прироста добычи угля или 1000 грн./т.

Современные потребности внутреннего Украинского рынка энергоносителей на уголь государственных шахт составляют 21,6 млн. т. Значительная доля рыночного спроса энергоносителей удовлетворяется за счёт импорта, несмотря на наличие собственной сырьевой базы, достаточной для удовлетворения не только спроса внутреннего рынка, но и для экспорта энергоносителей. Это факт и служит причиной того, что охарактеризованная выше «Стратегия...» 2017 года сочла возможным прогнозировать снижение энергетической импортозависимости Украины с 51,6 \% в 2015 году до 33 \% в 2025-2035 гг. Правда, не только за счёт интенсификации работы угольной отрасли. Однако положительная сторона развития государственного сектора угольной промышленности все же заключается в возможности определённого снижения потребностей в импортных закупках угля, которые в 2017 году составили 19 млн.т по средней цене 3370 грн./т. Годовые суммарные затраты на импорт угля в Украину составляют 64 млрд. грн. или \$2,6 млрд. USA.

В плане возможности интенсификации работы ОП «Шахта им. Д.Ф. Мельникова» является весьма показательной. Она относится ко второй группе шахт, характеризуется большими запасами угля и технической возможности наращивания производственной мощности. Средняя нагрузка на механизированную лаву составляет 1000 т в сутки.

В настоящее время работает 1 лава по пласту $K_{8}$. Подготовка новых лав позволит увеличить мощность шахты до 0,9 млн. т в год. Для ввода двух новых лав необходимо вскрыть уклонами новый горизонт 950 м.

В табл. 3 представлены прогнозные показатели деятельности шахты, зависящие от числа лав.

Представленный расчёт показывает, что ускоренное развитие государственных шахт подобного типа экономически целесообразно для ускоренного вывода Украины из имеющего место топливно-энергетического кризиса. 
Таблица 3 - Показатели работы шахты им. Д.Ф. Мельникова

\begin{tabular}{|l|c|c|c|}
\hline \multicolumn{1}{|c|}{ Число рабочих лав } & \multicolumn{3}{c|}{ Количество работающих лав } \\
\cline { 2 - 4 } & 1 & 2 & 3 \\
\hline Мощность шахты, млн.т/год & 0,30 & 0,60 & 0,9 \\
\hline Себестоимость добычи, грн./т & 1900 & 1200 & 1000 \\
\hline Затраты на добычу, млн.т/год & 570 & 720 & 900 \\
\hline Выход товарного угля, тыс.т & 180 & 360 & 540 \\
\hline Доход, млн. грн. & 486 & 972 & 1458 \\
\hline Экономия денежных средств, млн. грн. & -84 & 252 & 558 \\
\hline Экономия импортных затрат, млн. грн. & 607 & 1214 & 1820 \\
\hline Вклад шахты в богатство страны, млн. грн. & 523 & 1466 & 2378 \\
\hline Потребность в инвестициях, млн. грн. & - & 300 & 600 \\
\hline Окупаемость, лет & - & 0,2 & 0,25 \\
\hline
\end{tabular}

Между суммарной мощностью государственных шахт и необходимыми инвестициями имеют место соотношения, позволяющие оценить влияние развития угольной отрасли на экономику Украины.

Потребность в инвестициях I равна

$$
I=\Delta A_{\amalg} \cdot i
$$

где, $\Delta A_{ш}-$ прирост суммарной мощности шахт, млн.т; $i$ - удельные инвестиции на 1-й млн. прироста мощности, млн.грн/млн.т.

В табл. 4 представлены данные о потребности в инвестициях в зависимости от суммарной мощности государственных шахт и от удельных инвестиций $\left(i_{1}=600\right.$ грн./т и $i_{2}=1000$ грн./т).

Увеличение инвестиций и, как следствие, производственных мощностей шахт позволяет уменьшить затраты на импорт угля на величину

$$
\Delta I=\left(A_{\sigma}-\frac{I}{i} \cdot d\right) \cdot Ц_{i},
$$

где $A_{б}=21,6$ - базовая потребность Украины в импортном угле, млн.т.; $\bigsqcup_{i}=3370$ - цена импортного угля, грн./т; $d=0,6$ - выход товарного угля из рядового угля, доли.

В табл. 5 представлены прогнозные показатели работы государственных угольных предприятий в зависимости от их суммарной мощности.

Таблица 4 - Потребность в инвестициях (млрд. грн)

\begin{tabular}{|c|c|c|c|c|c|c|c|}
\hline \multicolumn{2}{|c|}{ Суммарная мощность шахт, млн.т/год } & 4,4 & 8,8 & 15,2 & 19,0 & 24,0 & 36,0 \\
\hline Потребность в инвестициях & $i_{1}=600$ & - & 2,64 & 5,28 & 8,76 & 11,8 & 16,3 \\
\cline { 2 - 9 } для развития шахт при $i_{1}$ и $i_{2}$ & $i_{2}=1000$ & - & 4,40 & 8,80 & 14,6 & 19,6 & 31,4 \\
\hline
\end{tabular}

Таблица 5 - Прогнозные показатели работы государственных шахт

\begin{tabular}{|l|c|c|c|c|c|c|}
\hline $\begin{array}{l}\text { Суммарная мощность шахт по рядовому углю, } \\
\text { млн.т в год }\end{array}$ & 4,4 & 8,8 & 13,2 & 19,0 & 24 & 36 \\
\hline $\begin{array}{l}\text { Выход товарной угольной продукции, млн.т угля в } \\
\text { год }\end{array}$ & 2,6 & 5,3 & 7,9 & 11,4 & 14,9 & 21,6 \\
\hline Средняя мощность по рядовому углю, тыс.т в год & 133 & 266 & 400 & 580 & 770 & 1100 \\
\hline Импорт товарного угля, млн.т в год & 19 & 16,3 & 14,7 & 10,2 & 6,7 & 0 \\
\hline $\begin{array}{l}\text { Потребность внутреннего рынка в товарном угле } \\
\text { государственных шахт, млн.т/год }\end{array}$ & 21,6 & 21,6 & 21,6 & 21,6 & 21,6 & 21,6 \\
\hline
\end{tabular}


Увеличение суммарной мощностей шахт (табл. 5) позволяет, увеличив среднюю мощность государственных шахт, снизить себестоимость добычи угля (см. формулу (1)).

Затраты на добычу угля увеличиваются прямо-пропорционально величине инвестиций в развитие государственного сектора шахтного фонда

$$
3=a \cdot\left(\frac{I}{i}-A_{\phi}\right)+b \cdot N_{\text {ш }} \text { млн. грн. }
$$

где, $A_{\phi}$ - фактическая мощность шахты, млн. т.; $N_{\text {ш }}$ - число государственных шахт, шт.

В табл. 6 представлены денежные потоки по направлениям использования и их баланс в зависимости от суммарной мощности государственных шахт.

Таблица 6 - Показатели затрат на добычу угля

\begin{tabular}{|l|c|c|c|c|c|c|}
\hline \multicolumn{1}{|c|}{$\begin{array}{c}\text { Суммарная мощность государственных шахт, } \\
\text { млн. т/год }\end{array}$} & 4,4 & 8,8 & 13,2 & 19,0 & 24,0 & 36 \\
\hline Затраты на добычу, млрд. грн./год & 18,9 & 18,8 & 21,1 & 24,0 & 27,4 & 32,9 \\
\hline Доход, млрд. грн. & 7,1 & 14,3 & 21,3 & 30,8 & 50,2 & 58,3 \\
\hline Прибыль, млрд. грн. & $-11,8$ & $-4,5$ & $+0,2$ & 6,8 & 22,8 & 25,4 \\
\hline Затраты на импорт угля, млрд.грн. & 64 & 54,9 & 49,5 & 34,4 & 22,5 & 0 \\
\hline Итого, затраты, млрд. грн. & 82,9 & 73,7 & 70,6 & 54,4 & 49,9 & 32,9 \\
\hline Эффективность инвестиций, млрд.грн./год & - & 9,2 & 12,5 & 35,3 & 55,8 & 75,4 \\
\hline
\end{tabular}

Эффективность инвестиций определяется по формуле

$$
\ni=3_{б}-\left(3_{д i}+3_{i}+\Pi_{i}\right)
$$

где $3_{б}$ - базовые затраты при суммарной мощности шахт 4,4 млн.т;

$$
3_{б}=64+18,9=82,9 \text { млрд. грн.; }
$$

$3_{\text {дi }}$ - затраты на добычу угля при $i$-том варианте суммарной мощности шахт, млрд. грн.; $3_{i}-$ затраты на импорт угля по $i$-тому варианту мощности шахты, млрд./грн.; $\Pi_{i}-$ прибыль шахты по $i$ - тому варианту суммарной добычи шахт, млрд. грн.

В табл. 7 представлен расчёт окупаемости инвестиций и их относительной эффективности, при удельной потребности в инвестициях $i_{2}=1000$ млн.грн. на один млн.т. прироста добычи.

Таблица 7 - Относительная эффективность и окупаемость инвестиций

\begin{tabular}{|l|c|c|c|c|c|c|}
\hline Суммарная мощность шахт, млн.т/год & 4,4 & 8,8 & 18,2 & 19,0 & 24,0 & 36,0 \\
\hline Потребность в инвестициях, млрд.грн./год & - & 4,4 & 8,8 & 14,1 & 19,6 & 31,4 \\
\hline Средняя мощность по рядовому углю, млн.т/год & 133 & 266 & 400 & 580 & 770 & 1100 \\
\hline Эффективность млрд. грн./ год & - & 9,2 & 12,5 & 35,3 & 55,8 & 75,4 \\
\hline Относительная эффективность, Э = эффективность & - & 2,1 & 1,4 & 2,5 & 2,8 & 2,4 \\
\hline Оквестиции & 1 & 0,48 & 0,7 & 0,4 & 0,36 & 0,42 \\
\hline
\end{tabular}

Как видно из табл. 7, развитие угольной промышленности Украины может быть весьма эффективно: на единицу вложенных средств в среднем экономится 2,2 единицы; при этом окупаемость инвестиций обеспечивается за 0,5 года. 
Финансирование «Программы...» было предусмотрено из двух источников: госбюджет - 50 \% и кредиты под гарантию государства - 50 \%. Альтернативными являются следующие схемы финансирования:

а) кредитная;

б) инновационно-инвестиционная;

в) лизинговая;

г) комбинированная.

Применение кредитной политики снимает ограничения финансирования «Программы...» по объёму бюджетных средств и позволяет в кратчайшие сроки ускоренным способом развить угольную промышленность государственного сектора до прибыльного и экспортного режима работы. Для угольной промышленности необходимо установить льготный режим кредитования.

Целесообразность реализации инвестиционной программы очевидна. Согласно «Закону об инновациях» [6, 7], финансовые инвестиции и инновации имеют одинаковую стоимость, но по-разному влияют на заёмный капитал.

ИГТМ НАН Украины за пятидесятилетний период создал инновационный потенциал, обеспечивающий совершенствование технологических схем шахт, в части обогащения, малой энергетики, определения запасов метана в угольных пластах, комплексной разработки метаноугольных месторождений, горного комплекса (охрана, поддержание, компоновки и оптимизация параметров выработок), дифференцированного подхода к выбору решений, отличающихся формами собственности, запасами угля и потребностью в инвестициях, комплексного подхода к обеспечению безопасности работ на основе совместного решения задач аэрогазогидротермопирогеомеханики.

Оптимальным является комбинированный вариант инвестирования: инновационный, кредитно-инвестиционный и лизинговый.

Опытом разработки инвестиционных программ установлено, что использование инноваций позволяет существенно снизить заёмный капитал (до 20-30 \%) и сокращает в 1,5-2,0 раза сроки реализации программы.

Применительно к «Программе...» развития государственного сектора угольной промышленности Украины вклад инноваций составит от 3 до 6 млрд. грн., а ежегодный вклад в богатство нации - до 15 млрд. грн. в год.

Пакет инновационных предложений по совершенствованию угольной отрасли разработан в ИГТМ НАН Украины и может быть использован при организации работ по реформированию предприятий угольной отрасли.

\section{Выводы}

1. Развитие и восстановление государственных угольных шахт увеличивает объём добываемого угля и полностью покрывает спрос внутреннего рынка Украины на угольный товар на - 15-20 млн. т/год, уменьшает затраты на импорт угля на 40-60 млрд. грн./год, обеспечивает работу шахт в прибыльном режиме и обеспечивает ежегодный вклад в богатство нации до 60 млрд. грн.

2. Для развития и восстановления шахт государственной собственности необходимы инвестиции в количестве 50-60 млрд. грн., окупаемых в течение 1-2 лет. 
3. Потребность в инвестициях на развитие государственных шахт может быть уменьшена до 30 \%, за счёт инноваций ИГТМ НАН Украины.

Для ускоренного развития и восстановления государственных шахт, необходимо разработать комплексный инновационно-инвестиционный проект. ИГТМ НАН Украины располагает кадрами и научным потенциалом, необходимым для разработки комплексного проекта.

\section{СПИСОК ЛИТЕРАТУРЫ}

1. Перелік пріоритетних тематичних напрямів наукових досліджень і науково-технічних розробок на період до 2020 року. Додаток до постанови Кабінету Міністрів України від 7 вересня 2011 р. № 942. - Київ, 2011.

2. Стратегія сталого розвитку «Україна-2020». Схвалено Указом Президента України від 12 січня 2015 року № 5/2015. - Київ, 2015.

3. План Пріоритетних дій Уряду на 2016 рік. III. Модернізація інфрраструктури. 3. Реформа вугільної промисловості. - Затверджено Розпорядженням Кабінету Міністрів України від 26.05.2016 року № 418-р. - Київ, 2016.

4. Концепція реформування та розвитку вугільної промисловості на період до 2020 року. Схвалено Розпорядженням Кабінету Міністрів України від 24.05.2017 року № 733-р. - Київ, 2017.

5. Нова енергетична стратегія України до 2035 року «Безпека, енергоефективність, конкурентоспроможність» (Проект). [Електронний ресурс] - Режим доступу: http: Енергостратегія_2035 2017-06-01_PDF.pdf

6. Закон України «Про інноваційну діяльність» / Відомості Верховної ради України (ВВР). - 2002 - № 36. - Ст. 266 (зі змінами - ВВР. - 2014. - № 2-3. - Ст. 41). - Київ, 2014.

7. О единой концепции техногенной безопасности угольных шахт / А.Ф. Булат, Т.В. Бунько, И.Е. Кокоулин [и др.] // Геотехническая механика: межвед. сб. науч. тр. / ИГТМ НАН Украины. - Днепропетровск, 2015. - Вып. 124. - С. 3-15.

\section{REFERENCES}

1. Cabinet of Ministers of Ukraine (2011), Perelik priorytetnykh tematychnykh napryamiv naukovykh doslidzhen I naukovo-tekhnichnykh rozrobok na period do 2020 roku. Dodatok do Postanovy Kabinetu Ministriv Ukrainy vid 7 veresnya 2011 r. № 942 [List of priority thematic directions of scientific researches and scientific and technical developments on a period to 2020 year. Addition to Decree Cabinet of Ministers of Ukraine from September, 7, 2011 № 942\}, Kiev, UA.

2. President of Ukraine (2015), Strategiya stalogo rozvytku "Ukraina-2020» / Skhvaleno Ukazom Prezidenta Ukrainy vid 12 sichnya 2015 roku № 5/2015 [Strategy of the steady development «Ukraine-2020». Approved by Decree of President of Ukraine from January, 12, 2015 № 5/2015], Kiev, UA.

3. Cabinet of Ministers of Ukraine (2016), Plan priorytetnykh diy Uryadu na 2016 rik. III. Modernizatsiya infrastruktury. 3 Reforma vugilnoi galuzi. Zatverdzheno Rozporyadzhennyam Kabinetu Ministriv Ukrainy vid 26.05.2016 roku № 418-r [Plan of Priority actions of Government on 2016 year. Ш. Modernization of infrastructure. 3. Reform of coal industry. Ratified by Order of Cabinet of Ministers of Ukraine from 26.05.2016 year № 418-r.], Kiev, UA.

4. Cabinet of Ministers of Ukraine (2017), Kontseptsiya reformuvannya ta rozvytku vugilnoi promyslovosti na period do 2020 roku. Skhvaleno Rozporyadzhennyam Kabinetu Ministriv Ukrainy vid 24.05.2017 roku № 733-r. [Conception of reformation and development of coal industry on a period to 2020 year. Approved by Order of Cabinet of Ministers of Ukraine from 24.05.2017 year № 733-r.], Kiev, UA.

5. Nova energetychna strategiya Ukrainydo 2035 roku «Bezpeka, energoefektyvnist, konkurentospromozhnist» (proekt) [New power strategy of Ukraine to 2035 year «Safety, energy-effectiveness, competitiveness» (Project)], available at:http: Енергостратегія_2035 2017-06-01 PDF.pdf

6. Supreme soviet of Ukraine (2014), "Law of Ukraine «About innovative activity»», Information of the Supreme soviet of Ukraine, 2002, № 36, Item 266 (with the changes - Information of the Supreme soviet of Ukraine,2014, № 2-3, Item 41), Kiev, UA.

7. Bulat, A.F., Bunko, T.V. and Kokoulin, I.E. [and all] (2015), "About single conception of technogen safety of coal mines", GeoTechnical Mechanics, no. 124, pp. 3-15.

\section{Про авторів}

Булат Анатолий Федорович, Академик Национальной академии наук Украины, доктор технических наук, профессор, директор института, Институт геотехнической механики им. Н.С. Полякова Национальной академии наук Украины (ИГТМ НАН Украины), Днепр, Украина, gtm.bulat@gmail.com

Шейко Анатолий Васильевич, магистр, главный технолог в отделе проблем технологии подземной разработки угольных месторождений, Институт геотехнической механики им. Н.С. Полякова НАН Украины (ИГТМ НАН Украины), Днепр, Украина, igtmdep16@gmail.com

Софийский Константин Константинович, доктор технических наук, профессор, заведующий отделом проблем технологии подземной разработки угольных месторождений, Институт геотехнической механики им. Н.С. Полякова НАН Украины (ИГТМ НАН Украины), Днепр, Украина, igtmdep16@gmail.com

Бунько Татьяна Викторовна, доктор технических наук, старший научный сотрудник в отделе проблем разработки месторождений на больших глубинах, Институт геотехнической механики им. Н.С. Полякова НАН Украины (ИГТМ НАН Украины), Днепр, Украина, bunko2017@ukr.net 


\section{About the authors}

Bulat Anatoly Fedorovich, Academician of the National Academy of Sciences of Ukraine, Doctor of Technical Sciences (D.Sc.), Professor, Director of the Institute, Institute of Geotechnical Mechanics named by N. Polyakov of National Academy of Science of Ukraine (IGTM NAS of Ukraine), Dnipro, Ukraine, gtm.bulat@gmail.com

Sheiko Anatoliy Vasilyevich, Vaster of Science, Chief Technologist in the Department of Underground Coal Mining Technology, Institute of Geotechnical Mechanics named by N. Polyakov of National Academy of Science of Ukraine (IGTM NAS of Ukraine), Dnipro, Ukraine, igtmdep16@gmail.com

Sofiyskiy Konstantin Konstantinovich, Doctor of Technical Sciences (D.Sc.), Professor, Head of the Department of Underground Coal Mining Technology, Institute of Geotechnical Mechanics named by N. Polyakov of National Academy of Science of Ukraine (IGTM NAS of Ukraine), Dnipro, Ukraine, igtmdep16@gmail.com

Bunko Tatyana Viktorovna, Doctor of Technical Sciences (D.Sc.), Senior Researcher, Senior Researcher in the Department of Mineral Mining at Great Depths, Institute of Geotechnical Mechanics named by N. Polyakov of National Academy of Science of Ukraine (IGTM NAS of Ukraine), Dnipro, Ukraine, bunko2017@ukr.net

Анотація. Внутрішній ринок України відчуває дефріцит у товарному кам'яному вугіллі в об'ємі 19-20 млн.т. При цьому на частку державного сектора вугільної промисловості у 2017 році припадало всього 4,4 млн. тонн здобутого вугілля. На імпорт вугілля щорічно витрачається 64 млрд.грн.

Альтернативним є рішення щодо відновлення промислового потенціалу шахт державного сектора України шляхом їх модернізацій на основі інновацій, позикових інвестицій і лізингу. Одним з важливих документів, націлених на рішення цієї задачі, $є$ Нова економічна стратегія України (HEC) на період до 2035 року «Безпека, енергоефективність, конкуренто-спроможність». Реалізація її положень дозволить збільшити потужності діючих шахт, понизити собівартість здобичі і витрати на імпорт вугілля, попутно видобувати метан вугільних родовищ, збільшити економічний потенціал і забезпечити енергетичну незалежність України. Для розвитку шахт необхідні великі фінансові ресурси \$1,0-1,5 млрд. USA. Їх мож-на зменшити на 20-30 \% на основі науково-інноваційного потенціалу академічних, галузе-вих і учбових інститутів України. Прискорений розвиток вугільних шахт державного сектора України забезпечить щорічне збільшення багатства нації на \$3 млрд. USA.

Типовим вугільним підприємством є шахта ім. Д.Ф. Мельникова, розвиток гірничих робіт на якій (введення двох додаткових лав) дозволить втричі (до 900 тис т/рік) збільшити її потужність і понизити собівартість вугілля, що видобувається, з 1900 до 1000 грн/т. Підвищення сумарної потужності шахт дозволить до 2035 року повністю відмовитися від імпорту, покривши його необхідну потребу в 21,5 млн.т/рік. Проведений розрахунок необхідних для цього інвестицій і оцінений термін їх окупності.

Ключові слова: промисловий потенціал шахт, собівартість здобичі, прискорений розвиток вуглевидобування, імпорт вугілля, інвестиції, окупність.

Annotation. The Ukrainian internal market experiences commodity anthracite shortage in amount of $19 \div 20$ million tons. In 2017 , share of the state sector in the coal industry was only 4.4 million tons of totally produced coal. Annual expenditures for the coal import are UAH 64 billion.

As an alternative is a proposal to restore industrial potential of the Ukrainian state mines through their modernizations on the basis of innovations, loan investments and leasing. In this context, one of the important documents is the New Economic Strategy of Ukraine (NES) "Safety, Energy-Effectiveness, Competitiveness" for the period till 2035. Realization of its regulations will increase productivity of operating mines, reduce prime costs of production and expenditures for the coal import, make it possible to obtain methane from the coal deposits, multiply economic potential and provide energy independence of Ukraine. Restoration of mines requires great financial resources - about USD 1.0-1.5 billion. This sum can be decreased by $20 \div 30 \%$ at the expense of scientific and innovative potential of academician, industrial and educational institutes of Ukraine. Rapid development of Ukrainian state coal mines will ensure annual increase of welfare of the country by USD 3 billion.

As an example is the D.F. Melnikov Mine - a typical coal enterprise: here, development of mining works (putting into operation of two additional longwalls) will ensure triple increase of production (up to 900 thousand tones/year) and reduce prime costs of coal from UAH 1900/ton to UAH 1000/ton. Total increase of production in all mines till 2035 will allow to fully give up the coal import by covering its share by own production in amount 21.5 million tons/year. In the article, calculation of the needed investments and time period for their recoupment is presented.

Keywords: industrial potential of mines, prime cost of production, rapid development of the coal mining, import of coal, investments, recoupment.

Статья поступила в редакцию 15.02 .2018

Рекомендовано к печати д-ром техн. наук С.П. Минеевым 